\title{
An Examination of the Achievement Levels of Acquisitions in Hybridization: High School Sample
}

\author{
Sevgül Çalış \\ Department of Science and Mathematics Education, Faculty of Education, Uludağ University, Görükle Campus, Turkey
}

Copyright $\subseteq 2018$ by authors, all rights reserved. Authors agree that this article remains permanently open access under the terms of the Creative Commons Attribution License 4.0 International License

\begin{abstract}
In this study with high school students, a descriptive scanning model, one of the qualitative research methods, was used to determine the extent to which the achievements of the hybridization occurred. The study was conducted with 12 th grade students studying in a public high school in Bursa in 2017-2018 academic year. According to the findings obtained from the research, it was determined that most of the high school students had difficulty in explaining the formation of single, double and triple bonds using atomic and hybrid orbital knowledge and expressing it verbally and schematically. It has also been found that students have problems in identifying the hybridization type which the central atom in the given organic compound undergoes. For this reason, it has been concluded that it is important to explain hybrids in detail at a high school level, taking advantage of teaching techniques and materials, paying attention to visuality during teaching and exploiting three-dimensional models.
\end{abstract}

Keywords Hybridization, Atomic Orbital, Hybrid Orbital, Chemistry Teaching

\section{Introduction}

When the achievements of hybridization are examined under the secondary education chemistry program, students are required to understand the hybrid orbitals and atomic orbitals and explain the formation of single, double and triple bonds. They are also expected to determine the hybridization pattern of the central atoms of molecules with different geometries. Students need to know atomic orbitals and chemical bonding to understand the hybridization process. In many studies, it has been shown that students have difficulty in recognizing chemical bonds [1-6]. It has also been found that students in different countries also have difficulties in distinguishing chemical bonds from each other [7-9]. The s, $p$ and $d$ atomic orbitals and hybrid orbitals, which are different mathematical mixtures of these orbits, need to be well known so that chemical bonds can be well explained, and more meaningful and effective learning can be achieved [10]. However, there are not enough studies in this regard. Only a few researchers have studied the difficulties that students have had in learning hybridization and the misconceptions of this subject [11-15].

In 1931, Pauling introduced the hypothesis of hybridization and gave an explanation for the four bonds being identical. According to the theory of hybridization, carbon's $\mathrm{s}$ and three $\mathrm{p}$ orbitals lose their atomic properties and make bonds by creating four identical orbits with unique features. Hybridization theory is a theory used to describe the bond structure of all single, double and triple bonds made by carbon and hetero atoms in the structure of organic molecules [16]. Like many other topics in chemistry, the concepts of atomic orbital and hybridization are also abstract, making them difficult to learn. There are not many studies that examine students' difficulties in learning hybridization concepts and their level of knowledge. For this reason, in order to determine the extent of the achievements of hybridization within the scope of the high school chemistry program, this study was aimed to overcome the deficiency in the field and the answers to the following questions were sought in consideration of the achievements in hybridization in the high school program.

1. What is the level of hybridization concept knowledge of high school students?

2. What is the level of knowledge of high school students about atomic orbital and hybrid orbital?

3. Can high school students explain the formation of single, double and triple bonds using atomic and hybrid orbital knowledge?

4. Can high school students determine the hybridization pattern of the central atom in the organic compounds given to them?

5. Can high school students make molecular models that show different hybrids with the materials given to them? 


\section{Materials and Methods}

\subsection{Design of the Study}

The descriptive screening model was used in this qualitative study aiming to determine the current knowledge of the 12th grade high school students about the hybridization topic and their hybridization acquisitions. The descriptive screening model is a research approach aimed at describing the event or situation as the subject of the research [17]

\subsection{Participants}

As the subject of hybridization took place in the 12th grade curriculum of secondary education, forty 12 th grade students formed the sample of the study. Sampling was used to identify the participants. In selecting the purposeful sample, it is thought that the criteria considered to be important for the research topic are determined and according to these criteria, it is thought that the selected sample can represent the research universe with all its qualities [18].

\subsection{Data Collection Tool}

Five open-ended questions were developed by the researcher as a means of data collection and the prepared questions were presented to two expert academicians in their field, and the questions' applicability was confirmed after the necessary corrections were made. In addition, measures have been taken to ensure external validity by clearly explaining the steps. After these stages, open-ended questions were formed. Examples of the questions in the mentioned below.

\section{Example Questions}

1. Explain how you can define the concept of hybridization.

2. Explain how the atomic s and $\mathrm{p}$ orbitals overlap to form sp., $\mathrm{sp}^{2}$ and $\mathrm{sp}^{3}$ hybrid orbitals in a scheme.

3. Indicate the central atom hybridization pattern in methane, ethene and ethyne compounds (show on the figure if you do not).

4. Are compounds other than carbon also showing hybridization? Explain by example.

5. Using the knot bar models distributed to you, construct compounds containing $\mathrm{sp}, \mathrm{sp}^{2}$ and $\mathrm{sp}^{3}$ hybrid orbitals.

Forms with open ended questions are given to the students and they are given an hour to answer them by writing clear explanations. After this stage, 6 students were selected based on volunteerism and interviews were held with these students for approximately one hour. During the interviews, the same questions were asked to the students again, and the answers given were noted.

\subsection{Data Analysis}

Qualitative data collected by open-ended questions in the study were analyzed according to 'content analysis' method. The main purpose of content analysis is to reach concepts and relationships that can explain the collected data [19]. In the analysis process, the ideas and approaches used to solve each problem are converted into short codes. In the process of coding the data, the data were evaluated several times and worked on and opinions were obtained from expert faculty members. In later stages, expressions containing similar thoughts and approaches continued to be examined in the generated codes were collected under more broad categories. The categories have also gone through the themes. The theme according to [19] is the upper concept created from the categories. It is a conceptual framework or a theoretical structure.

The data obtained in the study were analysed based on the themes of: the concept of hybridization, the concept of hybridization, the awareness of hybridization in molecules, and the use of information molecules in modeling.

In defining the concept of hybridization, high school students were asked to identify the word "hybridization". The first of the research questions prepared for the students was related to this theme. In this case, it was categorized as correct definitions, misidentifications and no definitions.

In terms of understanding the concept of hybridization, it is desirable to express the formation of hybrid orbitals. The identification of the hybridization strain depends on whether orbits that form hybridization are well known and understood. For this purpose, the research question number two is associated with this theme. Students are required to express the formation of $\mathrm{sp}, \mathrm{sp}^{2}$ and $\mathrm{sp}^{3}$ hybrid orbitals from atomic $\mathrm{s}$ and $\mathrm{p}$ orbitals by shape. For understanding the concept; categories such as understanding, misunderstanding and not understanding are made.

In the sense of recognizing hybridization in molecules; it is aimed to identify the hybridization type in different compounds given. For this purpose, it is desirable to specify hybridization of central atom in methane, ethene and ethyne molecules with different hybrids. When examining the achievements of the secondary chemistry program of the hybridization topic, it is also desired to determine the hybridization types of the compounds made by the hydrogen atoms of the second periodic elements other than the carbon atom, since learning of the compounds of the second periodic elements with hydrogen is also included in the acquisitions. To this end, research questions 3 and 4 have been associated with this theme. For that, the theme is categorized as correct display, wrong display and no answer.

The students were asked to make molecular models with different hybridization types by giving molecular model set to the students in order to use the information in 
creating the molecular model of the information, and the models they made are photographed. In this case, it is aimed to determine how students explain the formation of single, double and triple bonds with hybrid orbitals in the molecular models that they form. If the models made by the students overlap with the type of hybridization they describe, the model is considered to be appropriate and if they don't overlap, model is considered to be inappropriate. In addition, in the individual interviews made with 6 students, students were given more freedom in modeling by giving them knot-bar models as well as other materials such as game hurdles, toothpicks, paper, scissors and glue.

The study also included quotes from the views of the students. Each student has been given code names such as S1, S2, so that the students will have their own work sent directly.

\section{Results and Discussions}

1. In analyzing the first question for the concept of defining hybridization, student answers were examined one by one and the results given in Table 1 below were obtained

Table 1. Results of the analysis of the first research question for the concept definition

\begin{tabular}{|c|c|c|c|c|}
\hline Theme & Codes & $\mathrm{f}$ & $\%$ & Categories \\
\hline $\begin{array}{c}\text { Defining } \\
\text { Hybridization }\end{array}$ & $\begin{array}{l}\text { * Transformation of atoms and orbitals with different energy levels to } \\
\text { form new orbitals with same energy level. } \\
\text { * The transformation of s and } \mathrm{p} \text { orbitals into new orbitals by overlapping } \\
\text { such as } \mathrm{p}, \mathrm{sp}^{2} \mathrm{sp}^{3} \\
\text { * Bonds made by the carbon atom. } \\
\text { * Bringing different orbitals to the same energy level } \\
* \text { Carbon atom excitation } \\
* \text { No answer }\end{array}$ & $\begin{array}{c}8 \\
10 \\
4 \\
4\end{array}$ & $\begin{array}{l}15 \\
20 \\
20 \\
25 \\
10 \\
10\end{array}$ & $\begin{array}{c}\text { Correct identification } \\
\text { Incorrect identification }\end{array}$ \\
\hline
\end{tabular}

As seen in Table 1, the number of students who correctly explain the definition of the hybridization concept with their own census is $35 \%$. $20 \%$ of the students consider the bonds made by the carbon atom as hybridization, while $25 \%$ of the students define hybridization as bringing orbitals in different energy levels to the same energy level. The following are examples of answers given by students participating in the survey on the definition of the concept of hybridization.

S4: "s and $\mathrm{p}$ orbitals overlap to form $\mathrm{sp}, \mathrm{sp}^{2}, \mathrm{sp}^{3}$ orbitals"

S5: "The bond carbon atoms make "

S9: "Excitation of carbon atom

S14: "The formation of new orbitals by the joint use of orbitals"

$\mathrm{S} 22$ : "The transformation of $\mathrm{s}$ and $\mathrm{p}$ orbitals into new orbitals such as $\mathrm{sp}, \mathrm{sp}^{2}, \mathrm{sp}^{3 \text { " }}$

In analyzing the first question, which is asked to identify the concept of hybridization, the number of students who define hybridization correctly with their own census is $35 \%$. According to the definitions made by the students, "the formation of new orbitals with the same energy by the interaction of atoms and orbitals at different energy levels" and "the transformation of $\mathrm{s}$ and $\mathrm{p}$ orbitals into new orbitals like $\mathrm{sp}, \mathrm{sp}^{2}, \mathrm{sp}^{3}$ are coded as correct definitions. In the study, students' interpretation of the carbon atom's bonds as hybridization show that they are in a great error about chemical bonds. Another misconception is that carbon atom excitation is defined as hybridization. This error is clearly seen in the formal expression of the student coded as S14's definition of hybridization.

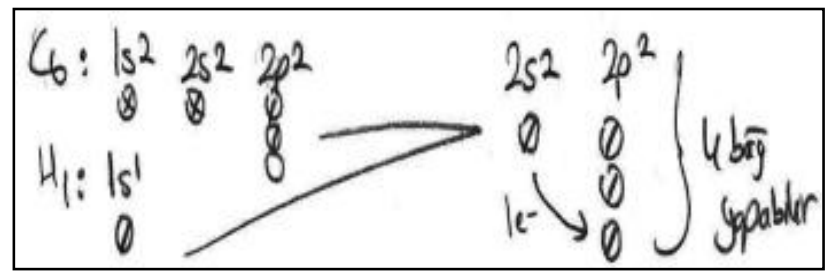

Figure 1. S14's definition of hybridization

When the figure drawn for the definition of hybridization by the S14 coded student is examined, it is seen that the student interpreted hybridization as passage of one the electrons from $2 \mathrm{~S}$ orbital in carbon atom's basic electron sequence to $2 \mathrm{P}$ orbital by excitation. These results support the finding that university students have similar misconceptions about atomic orbitals and hybridization in the work done by [12]. According to another study conducted with university students, seven categories of misconceptions related to chemical bonds of students were determined [5]. In our study, $25 \%$ of the students also wrote definitions for hybridization, which are similar to the expression "bringing different orbitals to the same energy". According to these definitions, students did not realize that orbitals participating in the hybridization event overlapped and formed new orbitals with brand new features. 
2. In the second question posed to understand the concept of hybridization, it is desirable to explain the formation of sp, $\mathrm{sp}^{2}$ and $\mathrm{sp}^{3}$ hybrid orbitals from atomic $\mathrm{s}$ and $\mathrm{p}$ orbitals in a formal way. According to the answers given to the second question, the results given in Table 2 below are obtained.

Table 2. Results of the analysis of the second research problem for the theme of understanding the concept

\begin{tabular}{|c|c|c|c|c|c|}
\hline Theme & Orbitals in $2^{\text {nd }}$ question & Codes & $\mathrm{f}$ & $\%$ & Categories \\
\hline \multirow{9}{*}{ Understanding the concept } & \multirow[t]{3}{*}{$\mathrm{sp}$} & *Correct & 10 & 25 & Comprehension \\
\hline & & *Incorrect & 18 & 45 & Misrecognition \\
\hline & & *No Answer & 12 & 30 & No comprehension \\
\hline & \multirow[t]{3}{*}{$\mathrm{sp}^{2}$} & * Correct & 10 & 25 & Comprehension \\
\hline & & *Incorrect & 18 & 45 & Misrecognition \\
\hline & & *No Answer & 12 & 30 & No comprehension \\
\hline & \multirow[t]{3}{*}{$\mathrm{sp}^{3}$} & * Correct & 10 & 25 & Comprehension \\
\hline & & *Incorrect & 16 & 40 & Misrecognition \\
\hline & & * No Answer & 14 & 35 & No comprehension \\
\hline
\end{tabular}

As seen in Table-2, students who can correctly show sp, $\mathrm{sp}^{2}$ and $\mathrm{sp}^{3}$ hybrid orbital formation is $25 \%$. These students have not indicated how many identical hybrid orbits are formed, although they can draw the formation of $\mathrm{sp}^{3}, \mathrm{sp}^{2}$ and sp hybrid orbital from the $\mathrm{p}$ orbital with s orbital. The opinions of some students on the formation of $\mathrm{sp}, \mathrm{sp}^{2}$ and $\mathrm{sp}^{3}$ hybrid orbitals are as follows:

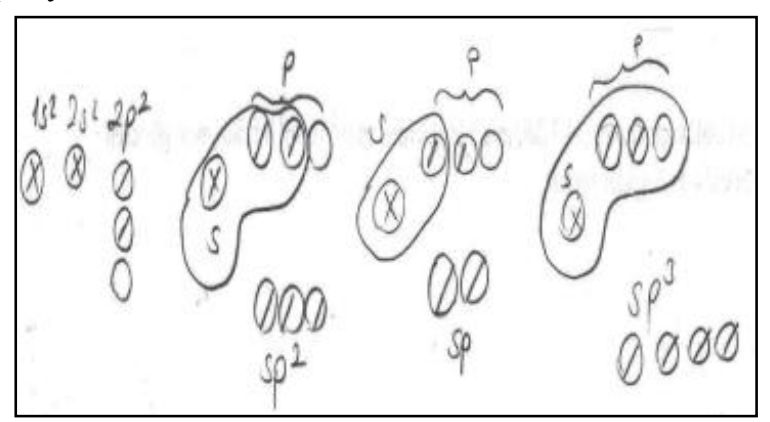

Figure 2A. Shape drawn by S25 to answer the $2^{\text {nd }}$ question to demonstrate $\mathrm{sp}, \mathrm{sp}^{2}$ and $\mathrm{sp}^{3}$ hybridization

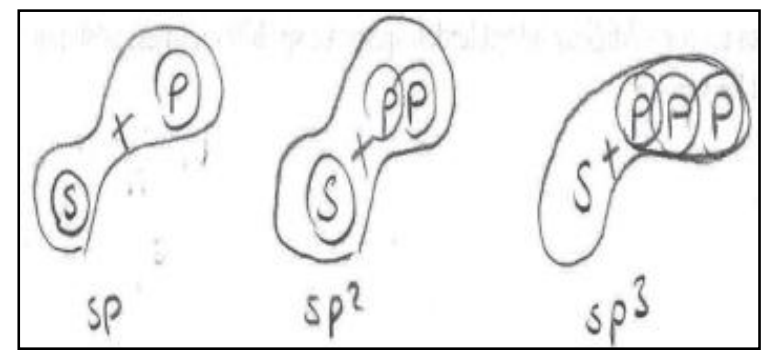

Figure 2B. Shape drawn by $S 9$ to answer the $2^{\text {nd }}$ question to demonstrate $\mathrm{sp}, \mathrm{sp}^{2}$ and $\mathrm{sp}^{3}$ hybridization
In the analysis for the second question, as seen in Table 2, $25 \%$ of the students are able to show the $\mathrm{sp}, \mathrm{sp}^{2}$ and $\mathrm{sp}^{3}$ hybrid orbital formations correctly and recognize these orbitals. These students also did not specify how many identical hybrid orbits were formed, although they could show the formation of $\mathrm{sp}^{3}, \mathrm{sp}^{2}$ and $\mathrm{sp}$ hybrid orbital from the $\mathrm{p}$ orbital with $\mathrm{s}$ orbital. Students who demonstrate hybrid orbital formation incorrectly appear to be unaware of the hybridization phenomenon. The electron sequence of the carbon atom is basic as shown in Figure 2A, and the result of the overlapping of electron-free $\mathrm{p}$ orbital with $\mathrm{s}$ orbital is expressed as the resultant hybridization. According to these results, it can be said that most of the students did not show the hybrid orbital formation correctly. This result is also seen as a result of students' tendency to learn by memorizing the hybridization phenomenon. In a study on chemical bonds, it has been stated that the atomic orbital, molecular orbital and hybridization topics are difficult to learn in chemistry [20]. Other studies with university students have also shown that students have difficulty in learning about atomic orbitals and hybrid orbitals and that these topics have not been learned sufficiently [11,21, 22].

3- Questions 3 and 4 have been asked for the recognition of hybridization in the molecules. In the analysis for the purpose of explaining the hybridization type of the central carbon atom in methane, ethene and ethyne compounds, student responses were examined one by one and the results given in Table 3 below were obtained 
Table 3. Results of the analysis of the third research problem for determining the hybridization type of the central carbon atom in methane, ethene and ethyne compounds

\begin{tabular}{|c|c|c|c|c|c|}
\hline Theme & Molecules in $3^{\text {rd }}$ question & Codes & $f$ & $\%$ & Categories \\
\hline $\begin{array}{l}\text { Awareness of } \\
\text { hybridization in } \\
\text { molecules }\end{array}$ & $\begin{array}{l}\text { Methane }\left(\mathrm{CH}_{4}\right) \\
\text { Ethene }\left(\mathrm{C}_{2} \mathrm{H}_{4}\right) \\
\text { Ethyne }\left(\mathrm{C}_{2} \mathrm{H}_{2}\right)\end{array}$ & $\begin{array}{l}\text { *To show } \mathrm{sp}^{3} \text { on the model } \\
\text { *Incorrect demonstration of the bonds } \\
\text { *Empty } \\
\text { *To show } \mathrm{sp}^{2} \text { on the model } \\
\text { *Incorrect demonstration of the bonds } \\
\text { *Empty } \\
\text { *To show sp on the model } \\
\text { *Incorrect demonstration of the bonds } \\
\text { *Empty }\end{array}$ & $\begin{array}{c}18 \\
12 \\
10 \\
\\
24 \\
6 \\
10 \\
\\
18 \\
12 \\
10 \\
\end{array}$ & $\begin{array}{l}45 \\
30 \\
25 \\
\\
60 \\
15 \\
25 \\
\\
45 \\
30 \\
25 \\
\end{array}$ & $\begin{array}{c}\text { Correct } \\
\text { Incorrect } \\
\text { No Answer } \\
\text { Correct } \\
\text { Incorrect } \\
\text { No Answer } \\
\text { Correct } \\
\text { Incorrect } \\
\text { No Answer }\end{array}$ \\
\hline
\end{tabular}

As shown in Table 3, the open formulas of the $\mathrm{CH}_{4}$, $\mathrm{C}_{2} \mathrm{H}_{4}$ and $\mathrm{C}_{2} \mathrm{H}_{2}$ compounds are shown, and the $\mathrm{sp}^{3}$ and $\mathrm{sp}^{2}$ and $\mathrm{sp}$ hybridizations of the central carbon atom hybridization types on the formula are shown correctly at $45 \%, 60 \%$ and $45 \%$, respectively. These compounds are highly recognizable in the entry point of organic chemistry because they are the basic compounds that are used extensively during the description of hybridization and molecular geometry. When the answers given by the students are examined, it has been determined that the mistakes made in determining the hybridization tendency of the central carbon atom are usually caused by mixing the $\mathrm{sp}^{3}$ hybrid orbital with the sp hybrid orbital.

The answers to some of the questions asked to the students in order to determine the hybridization of the central carbon atom are as follows:

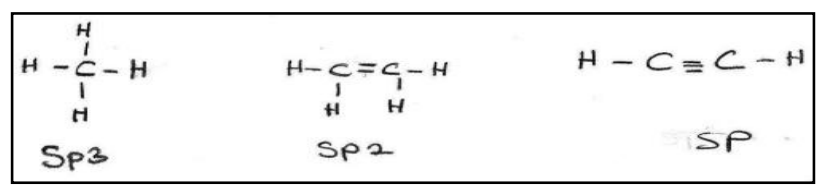

Figure 3. Shape drawn by $\mathrm{S} 27$ to answer the $2^{\text {nd }}$ to exemplify carbon central atom's hybridization

In the 4th question asked about the awareness of hybridization in the molecules, the information that the hybridization may be in other atoms besides carbon atom was examined and the results explained in Table- 4 were obtained.

Table 4. Analysis results for determining the information that hybridization may be outside the carbon atom

\begin{tabular}{|c|c|c|c|c|}
\hline Theme & Codes & $\mathrm{f}$ & $\%$ & Categories \\
\hline $\begin{array}{l}\text { Awareness of } \\
\text { hybridization } \\
\text { in molecules }\end{array}$ & $\begin{array}{c}* \mathrm{~N} \text { atom in } \mathrm{NH}_{3} \\
\text { compound } \\
* \mathrm{O} \text { atom in } \mathrm{H}_{2} \mathrm{O} \\
\text { compound } \\
* \mathrm{~B} \text { atom in } \mathrm{BH}_{3} \\
\text { compound } \\
* \text { No hybridization } \\
\text { except } \mathrm{C} \text { atom. } \\
* \text { Empty }\end{array}$ & $\begin{array}{l}14 \\
12 \\
6 \\
4 \\
4\end{array}$ & $\begin{array}{l}35 \\
30 \\
15 \\
10 \\
10\end{array}$ & $\begin{array}{l}\text { Incorrect } \\
\text { No answer }\end{array}$ \\
\hline
\end{tabular}

Students demonstrated that hybridization can also take place in other atoms besides carbon and gave compounds containing nitrogen, oxygen and boron as examples of these atoms. These compounds are $\mathrm{NH}_{3}, \mathrm{H}_{2} \mathrm{O}, \mathrm{BH}_{3}$ compounds. Some of the students' responses are as follows:

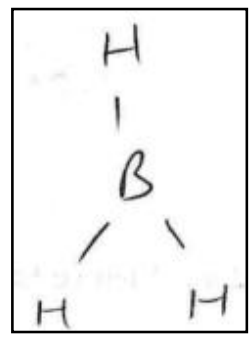

Figure 4A. Shape drawn by $\mathrm{S} 40$ of $\mathrm{BH}$

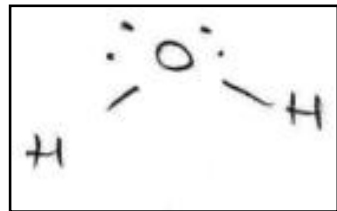

Figure 4B. Shape drawn by $\mathrm{S} 40$ of $\mathrm{NH}$

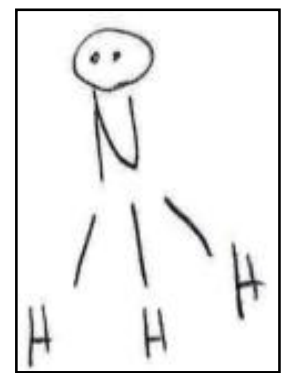

Figure 4C. Shape drawn by $\mathrm{S} 40$ of $\mathrm{H}_{2} \mathrm{O}$

According to Table $4,10 \%$ of the students stated that other atoms other than carbon could not hybridize. These results are consistent with the results of some previous studies. According to some studies; University students have stated that hybridization is only a carbon atomic feature $[23,24]$. 
4- It is desirable for the students to make molecular models that demonstrate hybridization in terms of using information to construct the molecular model.

The results given in Table-5 below were obtained by considering the student responses in the study

Table 5. Analysis results for determining the information that hybridization may be outside the carbon atom

\begin{tabular}{|c|c|c|c|c|}
\hline Theme & Codes & $\mathrm{f}$ & $\%$ & Categories \\
\hline & ${ }^{*} \mathrm{CH}_{4}$ molecule $-\mathrm{sp}^{3}$ & 30 & 75 & \\
& $* \mathrm{CH}_{3}-\mathrm{CH}_{3}$ molecule $-\mathrm{sp}^{3}$ & 30 & 75 & Correct \\
Using & ${ }^{*} \mathrm{CH}_{2}=\mathrm{CH}_{2}$ molecule $-\mathrm{sp}^{2}$ & 6 & 15 & match \\
information & $* \mathrm{NH}_{3}$ molecule $-\mathrm{sp}^{3}$ & 16 & 40 & \\
in making & $* \mathrm{H}_{2} \mathrm{O}$ molecule $-\mathrm{sp}^{3}$ & 18 & 45 & \\
molecular & $* \mathrm{BH}_{3}$ molecule $-\mathrm{sp}^{2}$ & 14 & 35 & \\
model & $* \mathrm{CO}_{2}$ molecule $-\mathrm{sp}^{2}$ & 10 & 25 & \\
& $* \mathrm{NH}_{3}$, molecule $-\mathrm{sp}^{2}$ & 8 & 20 & Incorrect \\
& $* \mathrm{H}_{2} \mathrm{O}$ molecule $-\mathrm{sp}^{2}$ & 6 & 15 & match \\
& $* \mathrm{BH}_{3}$ molecule $-\mathrm{sp}^{3}$ & 8 & 20 & \\
\hline
\end{tabular}

As it can be seen from Table 5, students are able to create different molecular models with the materials supplied to them. The most common molecular models are methane, ethane and water molecule. Some students matched the $\mathrm{CO}_{2}$ molecule with the $\mathrm{sp}^{2}$ hybridization due to double bond inclusion, and some matched the $\mathrm{NH}_{3}$ and $\mathrm{BH}_{3}$ compounds with the incorrect hybridization type. Students were found to be quite successful in creating ball bar models that were used to determine the benefits of using knowledge in modeling molecules. Students expressed a better understanding of the subject when they were taught more concrete visual objects. In addition, in the individual interviews made with 6 students, students were given more freedom in modeling by giving them ball-bar models as well as other materials such as game hurdles, toothpicks, paper, scissors and glue. As seen in the findings section, the student coded as S9 showed information about the molecular geometry by taping the unshared electrons existing on the $\mathrm{N}$ atom in the $\mathrm{NH}_{3}$ molecule onto a toothpick bar.

Examples of the molecular models made by the students coded S17, S19, S34 and S9 participating in the research are given below.

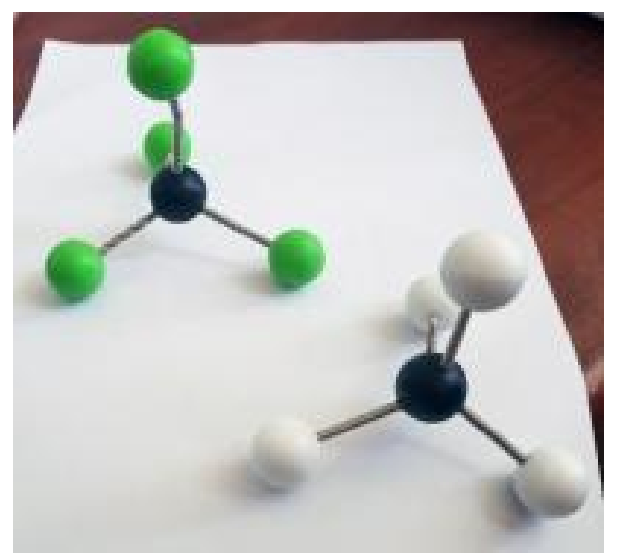

Figure 5A. Shape drawn using molecular model set by S19 of methane.

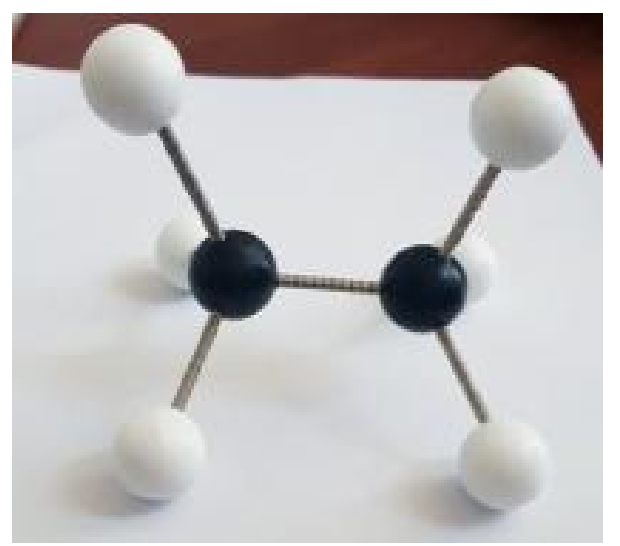

Figure 5B. Shape drawn using molecular model set by S17 of ethane.

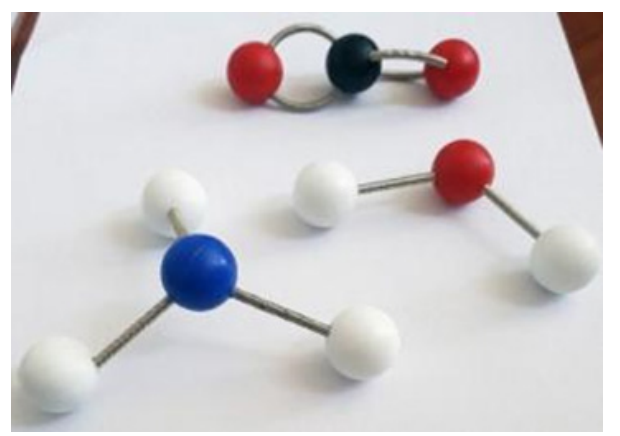

Figure 5C. Shape drawn using molecular model set by $\mathrm{S} 34$ of $\mathrm{BH}_{3}$, $\mathrm{H}_{2} \mathrm{O}, \mathrm{CO}_{2}$.

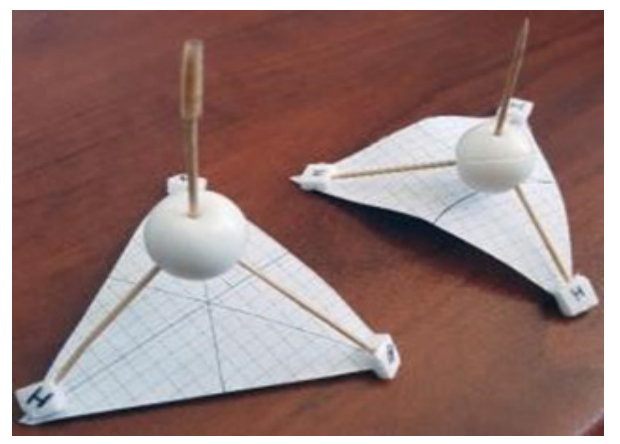

Figure 5D. Shape drawn using toothpicks by $\mathrm{S} 9$ of $\mathrm{NH}_{3}$.

\section{Conclusions}

Chemistry is regarded as a difficult science by educators and researchers interested in the field $[25,26]$. The fact that the concepts used in chemistry are abstract and the existence of symbols and equations in most of the subjects come at the beginning of the reasons why chemistry is difficult [27]. The concepts of atomic orbital and hybridization are among the subjects students have difficulties in learning because of their abstractness. The results of this study, which was conducted to determine the learning levels of the acquisitions of the subject of hybridization, also reveal the difficulties that students have experienced in learning hybridization. Good understanding 
of chemical bonds and molecular geometry is possible with the well-learned orbital and hybridization concepts. Because of hybridization and molecular geometry in organic chemistry are units among the 12th grade subjects of high school, there are also cases where students face questions about these topics in the entrance examinations to universities. The use of molecular models and information technologies (animation, simulation, video, etc.) in-class makes it easier for students to think of molecules in three dimensions and increases interest in the subject for realization of targeted gains in teaching program and more effective learning of students about hybridization. Good understanding of the atomic orbitals and hybridization topic is also an infrastructure for the teaching of hydrocarbons in organic chemistry. From this point of view, it can be said that the study will contribute to making the targeted gains in the curriculum a reality, in terms of attracting attention to both teachers and the education programmers.

\section{REFERENCES}

[1] Birk, J.P. ve Kurtz, M.J. (1999). "Effect of experience on retention and elimination of misconceptions about molecular structure ve bonding". Journal of Chemical Education, 76, 124-128.

[2] Harrison, A. G. ve Treagust, D. F. (2000). "Learning about atom, molecules, and chemical bonds: A case study of multiple-model use in grade 11 chemistry". Science Education, 84, 352-381

[3] Raymond F., R.F. Peterson and D.F. Treagust (1989). "Grade -12 Students' Misconception of Covalent Bonding and Structure" Journal of Chemical Education. 6 (66), 459-460.

[4] Kabapınar, F.M. ve Adik, B. (2006). Ortaöğretim öğrencilerinin kovalent bağda elektronların konum ve hareketlerini anlama biçimleri. M.Ü. Atatürk Ĕ̈itim Fakültesi Eğitim Bilimleri Dergisi, Sayı 23, Sayfa: 205-228

[5] Şen, Ş. ve Yılmaz, A. (2013). A Phenomenographic Study on Chemical Bonding. Necatibey Eğitim Fakültesi Elektronik Fen ve Matematik Eğitimi Dergisi (EFMED) Cilt 7, Say1 2. sayfa 144-177.

[6] Demirci, S., Yılmaz, A. ve Şahin, E. (2016). Lise ve üniversite öğrencilerinin atomun yapısı ile ilgili zihinsel modellerine genel bir bakış. Journal of the Turkish Chemical Society (JOTCS), Cilt: 1, Say1: 1, Sayfa 87-106.

[7] Adik, B. (2003). Ortaöğretim öğrencilerinin kimyasal bağ konusuna ilișkin yanılgıları ve bu yanılgıları besleyen düşünce biçimleri, Basılmamıș Yüksek Lisans Tezi, Marmara Üniversitesi, İstanbul.

[8] Levy Nahum, T., Hofstein, A., Mamlok-Naaman, R. ve Bar-Dov, Z. (2004). "Can final

[9] Ünal, S., Özmen, H. ve Demircioğlu, G. (2001). "Lise öğrencilerinin kimyasal bağlarla ilgili yanılgıları besleyen düsünce biçimleri, Basılmamıș Yüksek Lisans Tezi, Marmara Üniversitesi, İstanbul.

[10] Petrucci, R. H. \& Harwood, W. S. (1995). Turkish edition (Uyar, T., ed.). General chemistry: Principles and modern applications. Ankara: Palme Yayincilik.

[11] Salah, H. and Dumon, A. (2011). Conseptual integration of hybridization by Algerian students intending to teach physical science, Chem. Educ. Res. Pract., 2011, 12, 443453

[12] Nakiboglu C. (2003). Instructional misconceptions of Turkish prospective chemistry teachers about atomic orbitals and hybridization, Chem. Educ. Res. Pract., 4(2), 171-188.

[13] Zoller, U. (1990). Students' misunderstandings and misconceptions in college freshman chemistry (general and organic). Journal of Research in Science Teaching, 27, 1053-1065

[14] Taber, K.S. (2001). Building the structural concepts of Chemistry: Some considerations from educational research. Chemistry Education: Research and Practice in Europe, 2, 123-158. [http://www.uoi.gr/cerp]

[15] Taber, K.S. (2002). Compounding quanta: Probing the frontiers of student understanding of molecular orbitals. ChemistryEducation: Research and Practice in Europe, 3, 159-173. [http://www.uoi.gr/cerp]

[16] Atasoy, B.(2018).Genel Kimya,Ankara, Koza Yayıncılık.

[17] Karasar, N. (2002). Bilimsel Araştırma Yöntemi. Ankara: Nobel Yayın Dağıtım Ltd. Şti.

[18] Yıldırım, A. ve Şimşek, H. (2006). Sosyal bilimlerde nitel araştırma yöntemleri. Ankara: Seçkin Yayıncılık.

[19] Çepni, S. (2014). Araştırma ve Proje Çalışmalarına Giriş, Trabzon, Celepler Matbaacılık, 7.bask1

[20] Nahum, T. L., Mamlok-Naaman, R., Hofstein, A. and Krajcik, J. (2007). Developing a New Teaching Approach for the Chemical Bonding Concept Aligned with Current Scientific and Pedagogical Knowledge. Science Education, 91(4), 579-603.

[21] Bouayad, A., Kaddari, F., Lachkar.M. and Elechgar, A. (2014). Quantum Model of Chemical Bonding: Barriers and Learning Difficulties Procedia -Social and Behavioral Sciences, Volume 116, 21 Pages 4612-4616

[22] Tsaparlis G. (1997), Atomic orbitals, molecular orbitals and related concepts: conceptual difficulties among chemistry students, Res. Sci. Edu., 27(2), 271-287.

[23] McMurry, J. and Fay, R. C. (1998). Chemistry. New Jersey: Prentice Hall. misconceptions about molecular structure ve bonding". Journal of Chemical molecules: Implications for teaching chemistry". Science Education, 80, 509-534.

[24] Douglas, B., McDaniel D. and Alexander, J. (1994). Concepts and models of inorganic chemistry. J. Chem. Educ., 1994, 71 (9), p A239

[25] Nakiboğlu, C. ve Kalın, Ş. (2009). Ortaöğretim Öğrencilerinin Kimyada Problem Çözme Basamaklarının Kullanımı İle İlgili Düşünceleri. Kastamonu Eğitim Dergisi, 
$17(2), 715-725$.

[26] Tseitlin, M. and Galili, I. (2006). Science Teaching: What Does It Mean? Science and Education, 15(5), 393-417.
[27] Doymuş, K. (2007). The Effect of a Cooperative Learning Strategy in the Teaching of Phase and One-Component Phase Diagrams. Journal of Chemical Education, 84 (11), 1857-1860. 